\title{
Kewenangan Kepala Desa dalam Rekrutmen Perangkat Desa di Desa Longeo Utama, Kecamatan Asera, Kabupaten Konawe Utara
}

\author{
Ciang Windasari ${ }^{1}$; Muh. Nasir ${ }^{2}$; Saidin $^{3 ;}$ Asriani $^{4}$ \\ ${ }^{1234}$ Universitas Halu Oleo, Ciangwindasari@gmail.com
}

\begin{abstract}
Abstrak
Penelitian ini bertujuan untuk mengetahui dan mengambarkan Bagaimana Kewenangan Kepala Desa dalam Rekrutmen Perangkat Desa di Kabupaten Konawe Utara Khususnya di Desa Longeo Utama serta faktor-faktor yang mempengaruhi proses rekrutmen Perangkat Desa di Desa Longeo Utama. Penelitian ini di lakukan Di Desa Longeo Utama Kecamatan Asera Kabupaten Konawe Utara Sulawesi Tenggara menggunakan metode Kualitatif data yang di peroleh dari observasi, wawancara, dokumentasi. Hasil penelitian ini bahwa wewenang Kepala Desa Longeo Utama dalam melaksanakan Rekrutmen Perangkat Desa sesuai dengan peraturan menteri Nomor 85 Tahun 2015 tentang pengangkatan dan pemberhentian perangkat desa. Dalam proses rekrutmen perangkat desa memiliki faktor penghambat dan pendukung. Faktor penghambat yakni kurangnya anggaran untuk memaksimalkan kegiatan dan minimnya jumlah pendaftar yang memiliki kompetensi yang baik. Sedangkan faktor pendukung dalam rekrutmen perangkat desa yakni sudah adanya papan informasi yang terpercaya sebagai sumber informasi masyarakat, kegiatan sosialisasi keliling yang dilakukan oleh tokoh masyarakat, dan dukungan dari masyarakat Desa Longeo Utama untuk berpartisipasi dalam kegiatan rekrutmen tersebut.
\end{abstract}

Kata kunci : Desa Longeo, Kewenangan Kepala Desa, Rekrutmen Perangkat Desa,

\begin{abstract}
This study aims to describe how the authority of the village head in the recruitment of village officials in North Konawe Regency, especially in Longeo Utama village and the factors that influence the recruitment process of village officials in Longeo Utama village. This research was conducted in Longeo Utama Village, Asera District, Konawe Utara Regency, Southeast Sulawesi using qualitative methods. Data obtained from observations, interviews, documentation. The results of this study found that the authority of the Village Head of Longeo Utama in carrying out Village Apparatus Recruitment is under ministerial regulation Number 85 of 2015 concerning the appointment and dismissal of village officials. In the recruitment process, village officials have inhibiting and supporting factors. The inhibiting factors are the lack of budget to maximize activities and the minimum number of applicants who have useful competence. While the supporting factors in the recruitment of village officials are the existence of a reliable information board as a source of community information, mobile outreach activities carried out by community leaders, and support from the people of Longeo Utama Village to participate in the recruitment activity.

Keywords: Authority of the Village Head, Village Staff Recruitment, Longeo Village
\end{abstract}




\section{Pendahuluan}

Bentuk perhatian Pemerintah Pusat untuk membangun dan Indonesia dari Desa dituangkan Undang-Undang Desa Nomor 6 tahun 2014. mengingat bahwa Indonesia memiliki 70 ribu lebih desa, dari total keseluruhan desa yang terletak diseluruh pedalaman Indonesia. Baik itu desa yang masih tertinggal hingga desa yang sudah maju dan berkembang.

Pembangunan desa merupakan prioritas pembangunan pemerintah karena manjunya dan sejahteranya masyarakat desa merupakan cerminan ukuran keberhasilan pemerintah dalam pembangunan. Masalah-masalah umum pembangunan pedesaan seperti isu kemiskinan, kesehatan, peningkatan kualitas sumber daya manusia, dan infrastruktur sebagai penunjang mobilitas masyarakat desa.

Berdasarkan masalah tersebut seluruh tingkatan masyarakat dan pemerintah desa bertanggung jawab menangani hal tersebut. Diharapkan seluruh desa di Indonesia berupaya membangun kemandirian suatu masyarakat desa yang mandiri dan sejahtera. apalagi pelimpahan kewenangan dan hak penuh terhadap desa melalui Undang-Undang Nomor 6 Tahun 2014 Tentang Desa memberikan ruang bagi desa ikut serta dalam proses pembangunan

Dalam undang-undang tersebut telah diatur sedemikian mungkin seperti peran dan fungsi serta partisipasi aparatur pemerintah desa maupun masyarakat untuk mewujudkan kemajuan dan kemandirian desa. Kemudian, kapasitas dari elemen pemerintahan desa maupun masyarakat juga menjadi pendorong bagi majunya suatu desa. Sehingga memiliki aparatur pemerintah dan perangkat desa yang memiliki kemampuan yang baik dalam menjalankan tugasnya mutlak diperlukan. Mengingat permasalahan yang umum ditemukan di Desa seperti kurangnya kompetensi yang dimiliki oleh aparatur pemerintah Desa.

Sedangkan agar dapat berhasil menuju pada kesejahteraan masyarakat dan dapat menciptakan suatu sistem pemerintahan yang baik (good governance). Penyelenggaraan pemerintah desa, perlu disokong oleh perangkat desa yang memiliki peran yang mampu menciptakan tata pemerintahan yang baik. Hal ini 
kemudian menguatkan posisi perangkat desa yang sangat penting dalam membantu tugas dan kewenangan Kepala Desa (Selvia \& Rodiyah, 2020)

Namun, permasalahan terkait kapasitas dan kompetensi perangkat desa dimulai dari proses pelaksanaan seleksi. tingginya minat masyarakat desa mengikuti seleksi untuk menjadi bagian perangkat desa turut menghadirkan masalah saat proses seleksi perangkat desa, pendaftar yang tidak memiliki latar belakang, atau kemampuan dibidangnya, selain itu isu nepotisme dalam pemilihan perangkat desa menjadi sorotan.

Isu tersebut juga hadir dalam proses rekrutmen kepala desa longeo utama, dari wawancara awal dengan masyarakat didapatkan informasi bahwa dalam pelaksanaan rekrutmen perangkat desa di Desa Longeo Utama masih ditemukan masyarakat yang meminta secara langsung kepada Kepala Desa agar dijadikan Perangkat Desa. Informasi yang lain juga bahwa terdapat perangkat desa yang digantikan secara tidak wajar. Studi ini kemudian perlu dilakukan untuk menganalisis Kewenangan Kepala Desa dalam Rekrutmen Perangkat Desa di Kabupaten Konawe Utara, khususnya di Desa Longeo Utama dan mengetahui Kendala yang dihadapi dalam Pelaksanaan Rekrutmen Perangkat Desa di Desa Longeo Utama.

\section{Metode}

Jenis penelitian ini adalah deskriptif dengan pendekatan kualitatif. Penelitian ini akan menganalisis tentang wewenang Kepala Desa dalam pelaksanaan rekrutmen Perangkat Desa di Desa Longeo Utama Kecamatan Asera Kabupaten Kolaka Utara dengan mengandalkan dengan pendekatan kualitatif yang diperoleh langsung dari lokasi penelitian atau dari konteks kerja Kepala Desa. Sumber data diperoleh dari informan yang akan diambil dari subyek penelitian maupun dari pihak-pihak di luar subyek penelitian namun yang memiliki informasi yang diperlukan. Informan tersebut yaitu sebagai berikut: Kepala Desa Longeo Utama, Sekretaris Desa Longeo Utama, Perangkat Desa Longeo Utama, Tokoh Masyarakat, dan Masyarakat Desa Longeo Utama. Teknik yang akan digunakan dalam mengumpulkan data yang diperlukan dalam penelitian yaitu observasi, 
wawancara, dan dokumentasi. Adapun teknik analisis data yang digunakan dalam penelitian ini terdiri dari tahap reduksi data, tahap penyajian data, dan tahap penarikan kesimpulan (Miles, Huberman, 2005).

\section{Hasil dan Pembahasan}

\section{Wewenang Kepala Desa dalam Rekrutmen Perangkat Desa}

Dalam peraturan menteri Nomor 85 Tahun 2015 tentang pengangkatan dan pemberhentian perangkat desa wewenang Kepala Yakni membentuk Tim yang terdiri dari seorang ketua, seorang sekretaris dan minimal seorang anggota, melakukan penjaringan dan penyaringan calon Perangkat Desa yang dilakukan oleh Tim. Dalam Pelaksanaan penjaringan dan penyaringan bakal calon Perangkat Desa dilaksanakan paling lama 2 (dua) bulan setelah jabatan perangkat desa kosong atau diberhentikan. Hasil penjaringan dan penyaringan bakal calon Perangkat Desa paling sedikit 2 (dua) orang calon dikonsultasikan oleh Kepala Desa kepada Camat. Setelah Kepala Desa telah melaksanakan penjaringan dan telah merekomendasikan kepada Camat maka Camat memberikan rekomendasi tertulis terhadap calon Perangkat Desa paling lambat 7 (tujuh) hari kerja. Rekomendasi yang diberikan Camat berupa persetujuan atau penolakan berdasarkan persyaratan yang ditentukan. Dalam hal Camat memberikan persetujuan, Kepala Desa menerbitkan Keputusan Kepala Desa tentang Pengangkatan Perangkat Desa Dan Dalam hal rekomendasi Camat berisi penolakan, Kepala Desa melakukan penjaringan dan penyaringan kembali calon Perangkat Desa

\section{a. Kepala Desa membentuk Tim Seleksi}

Kepala Desa Longeo pada akhir bulan Juni 2018 telah melaksanakan rekrutmen Perangkat Desa. Rekrutmen yang dimaksud adalah memilih Tim seleksi yang terdiri dari Ketua, Sekretaris, Bendahara, dan Anggota. Upaya pembentukan Tim seleksi rekrutmen ini untuk mempermudah pekerjaan Pemerintah Desa dalam melaksanakan Rekrutmen Perangkat Desa yang sesuai dengan peraturan menteri Nomor 85 Tahun 2015 tentang pengangkatan dan pemberhentian perangkat desa. Namun dalam penerapannya Kepala Desa Longeo Utama hanya menunjuk salah 
seorang yang menjadi kepercayaan Kepala Desa untuk melakukan rekrutmen Perangkat Desa.

Seseorang yang ditunjuk untuk membantu Kepala Desa dalam merekrut perangkat desa merupakan orang- orang yang diambil dari masyarakat setempat yang telah berpengalam dan memiliki pendidikan yang layak sehingga rekrutmen yang diharapkan mampu berjalan sesuai dengan yang diharapkan.

Adapun daftar tim seleksi yang telah di bentuk oleh Kepala Desa adalah sebagai berikut:

Tabel 1. Nama Tim Seleksi Rekrutmen Perangkat Desa

\begin{tabular}{|c|c|c|c|}
\hline No & Nama & Jabatan & Pendidikan \\
\hline 1 & Kawela & Ketua Seleksi & SMA \\
\hline 2 & Usman & Sekretaris & SMA \\
\hline 3 & Munir & Anggota & SMA \\
\hline 4 & Karmila & Anggota & SMA \\
\hline
\end{tabular}

Sumber : Kantor Kepala Desa Longeo Utama Tahun 2018

Ketua Tim seleksi yang telah dibentuk bertugas untuk melakukan koordinasi dan perencanaan terkait rekrutmen kepala desa bersama Kepala Desa. Ketua Tim Seleksi melaksanakan Sosialisasi terkait Pembukaan Rekrutmen Perangkat Desa Oleh masyarakat yang terkait melalui beberapa cara diantaranya mengumumkan di mesjid, membuat banner, dan silaturahim secara langsung oleh masyarakat melaui hubungan kemasyarakatan. Ketua Tim seleksi juga harus memaksimalkan struktur yang telah dibuat dengan Kepala Desa secara maksimal agar rekruitmen perangkat desa dapat berjalan dengan sesuai yang diharapkan.

Selanjutnya, sekretaris yang telah dibentuk sebagai tim seleksi bertugas dalam menertibkan administrasi terkait pendaftaran perangkat desa. Sekretaris yang telah dibentuk akan mendata peserta yang mencalonkan untuk kemudian dilakukan pemberkasan untuk memastikan layak atau tidaknya di terima sebagai perangkat desa. Sedangkan Ketua Tim seleksi bertugas untuk menyusun rencana anggaran yang akan di butuhkan dalam proses rekrutmen perangkat desa. Dalam mempermudah tugas-tugas tim seleksi dibantu oleh beberapa orang anggota yang telah di pilih untuk melaksanakan proses sosialisas, perlengkapan dan sampai pada tahap verifikasi. 
Dalam tahap ini Kepala Desa bersama Tim Seleksi telah melakukan koordinasi dalam pelaksanaan rekrutmen perangkat desa. Kepala Desa dalam melaksanakan Rekrutmen perangkat Desa membentuk Tim Rekrutmen yang terdiri dari Ketua, Sekretaris, dua orang anggota. Dalam melaksanakan wewenangnya, Kepala Desa dalam melaksanakan Rekrutmen Perangkat Desa membentuk Tim yang terdiri dari Ketua, Sekretaris, dan 2 Anggota telah sesuai dengan peraturan menteri Nomor 85 Tahun 2015 tentang pengangkatan dan pemberhentian perangkat desa

\section{b. Kepala Desa Melakukan Penjaringan dan Penyaringan}

Kepala Desa mempunyai wewenang untuk membentuk Tim seleksi perangkat desa. Pada tahap selanjutnya Kepala Desa melakukan penjaringan dan penyaringan calon peserta yang dibantu oleh Tim yang telah di bentuk. Dalam tahap ini ada beberapa mekanisme seleksi yang akan dilakukan untuk mengetahui apakah peserta seleksi layak menjadi perangkat desa. Penjaringan tersebut telah di rencanakan oleh Tim seleksi yang di setujui oleh kepala desa tersebut.

Dalam rekrutmen perangkat desa masih di temukan masyarakat yang meminta secara langsung untuk menjadi perangkat desa tanpa melalui tahap yang telah ditentukan. Hal demikian juga di ungkapkan dalam wawancara oleh masyarakat Desa Longeo Utama, Ramlia mengatakan bahwa "Masih banyak masyarakat yang meminta langsung karena alasan keluarga, namun yang meminta itu kebanyakan diterimah. Saya yakin bila yang meminta adalah keluarganya pasti di terimah." (Ramlia 20 Januari 2020)

Pernyataan masyarakat Desa Longeo tersebut mengatakan bahwa dalam rekrutmen perangkat desa masih banyak masyarakat yang meminta langsung untuk dijadikan perangkat desa dengan alasan mempunyai ikatan kekeluargaan. Namun demikian pernyataan tersebut tidak dibenarkan oleh Kepala Desa yang mengatakan bahwa: "Memang benar banyak yang meminta bahkan kebanyakan keluarga saya, namun kebanyakan dari mereka tidak memenuhi persyaratan dengan kata lain tidak memiliki pendidikan yang jelas sehingga kami tolak. Memang ada keluarga saya yang menjadi perangkat desa tetapi mereka memang layak baik dalam segi pendidikan maupun pengalaman.” (Resmin, 20 Januari 2020) 
Dari hasil wawancara dengan Ketua Tim Seleksi bahwa yang ingin menjadi perangkat desa memang banyak, mereka semua meminta secara langsung baik dari ketua tim seleksi maupun dari kepala desa. Namun panitia menegaskan agar melakukan sesuai dengan proses tahapan yang disyaratkan dimulai dari kelengkapan berkas pendaftar.

Pernyataan di atas merupakan jawaban dari asumsi masyarakat yang mengatakan bahwa Kepala Desa Longeo utama mengangkat perangkat desa yang meminta langsung dengan alasan keluarga tidak lah sejalan dengan keadaan yang sebenarnya. Kepala Desa beserta tim seleksi membenarkan bahwa masih ada masyarakat yang meminta menjadi perangkat desa namun tidak semestinya diterimah dengan alasan harus mengikuti ketentuan dan prosedur yang berlaku. Perangkat Desa yang telah diangkat merupakan orang-orang yang memiliki pendidikan dan pengalaman yang jelas dan memang berhak menjadi perangkat desa.

Adapun tahapan penjaringan dan penyaringan peserta calon perangkat desa yang terpilih telah melaksanakan penjaringan sebagai berikut:

\section{1) Persyaratan Calon Peserta}

Ketentuan dan persyaratan tersebut disesuaikan dengan kebutuhan Kepala desa dalam melaksanakan tugas dan tanggung jawab. Dari hasil wawancara yang dengan Ketua Panitia Seleksi Perangkat Desa dan Kepala Desa bahwa tidak banyak persyaratan yang dipenuhi karena mempertimbangkan Sumber Daya Manusia yang masih sangat minim, yang terpenting adalah Ijazah dan Surat Keterangan Siap untuk mengembang tugas sebagai Perangkat Desa. Kepala Desa mengamanahkan kepada panitia seleksi agar tidak memberatkan masyarakat untuk bisa bergabung sebagai Perangkat Desa, adapun format tanda tangan sudah di siapkan oleh Sekretaris desa tinggal mereka menyediakan materai.

\section{2) Tahap Sosialisasi}

Tahap sosialisi ini merupakan tahap dari penjaringan Calon Perangkat Desa yang dilakukan selama 6 hari oleh Kepala Desa beserta Panitia Seleksi dengan cara menyampaikan informasi terkait rekrutmen Perangkat Desa keseluruh bagian dan 
unsur-unsur desa untuk memberikan kesempatan terhadap msayarakat yang mempunyai kemampuan dan pendidikan yang layak untuk bisa bergabung.

Sosialisasi bertujuan agar semua masyarakat tau bahwa rekrutmen proses sedang dilaksanakan serta membuka kesempatan untuk bergabung dan menjadi bagian dari perangkat desa dengan mempersiapkan berkasnya. Sosialisasi sampaikan langsung baik kepada ketua RT, tokoh masyarakat, bahkan sampai di tempat peribadatan seperti mengumumkan di masjid bahwa siapa saja yang ingin mendaftar menjadi perangkat desa silahkan menghubungi lebih lanjut pada Aparatur Desa atau Ketua Tim seleksi. Masyarakat pun mendengar secara langsung sosialisasi yang di sampaikan langsung oleh Kepala Desa bersama kepala Dusun, Tokoh masyarakat yang juga disampaikan di masjid.

Berdasarkan hasil wawancara diatas bahwa dalam pelaksanaan Rekrutmen Perangkat Desa Kepala Desa melaksanakan sosialisasi terkait pengumuman rekrutmen Perangkat Desa. Sosialisasi Perangkat Desa tersebut merupakan usaha Kepala Desa dalam mengembalikan kepercayaan terhadap masyarakat terkait Transparansi dalam Rekrutmen Perangkat Desa.

\section{3) Pelaksanaan Seleksi}

Tahap pelaksanaan seleksi dan penjaringan ini merupakan tahap yang menentukan apakah peserta rekrutmen Perangkat desa layak atau tidak menjadi bagian dari pemerintahan desa. Dalam tahap ini peserta di arahkan untuk melengkapi berkas, melakukan ujian tertulis dan yang terakkhir melakukan wawancara. Dalam pelaksanaan penjaringan Kepala Desa memberi kewenangan penuh untuk menjaring para peserta. Hasil dari penjaringan tersebut dilaporkan Oleh Kepala Desa sebagai bahan pertimbangan.

Rangkaian pelaksanaan seleksi belum sepenuhnya berjalan sesuai dengan semestinya karena kendala Sumber daya manusia. Salah satu tahap seleksi yang belum berjalan sesuai dengan peraturan yang berlaku adalah pada saat pelaksanaan wawancara. Kurangnya pemahaman tentang materi wawancara sehingga tim seleksi belum mampui untuk menerapkan tahap wawancara. Kepala Desa Longe Utama telah melaksanakan wewenangnya dalam melaksanakan Penjaringan Peserta Calon Perangkat Desa. Dalam malaksanakan penjaringan Kepala Desa 
beserta Tim Seleksi Rekrutmen telah melakukan Sosialisasi, pemberkasan, tes tertulis, dan wawancara. Namun dalam penerapannya tahap wawancara belum bisa dilaksanakan sesuai dengan aturan yang berlaku dikarenakan Sumber Daya Manusia yang terbatas.

\section{c. Kepala Desa merekomendasikan Calon Perangkat Kepada Camat}

Pelaksanaan rekrutmen perangkat desa tidaklah di tentukan mutlak oleh Kepala Desa dalam memilih dan mengangkat Perangkat Desa namun harus mendapatkan persetujuan oleh Camat sesuai dengan peraturan dan perundangundangan yang berlaku. Kepala Desa hanya berwenang untuk melakukan penjaringan terhadap Calon Perangkat Desa sesuai dengan peraturan menteri Nomor 85 Tahun 2015 tentang pengangkatan dan pemberhentian perangkat desa. Dari hasil wawancara dengan kepala desa bahwa setelah melaksanakan pemberkasan maka sudah ada 7 Calon yang telah direkomendasikan kepada camat untuk di tindak lanjuti. Kepala Desa tidak berhak untuk menentukan dan mengangkat sendiri tanpa ada persetujuan dan pertimbangan dari Camat

Wewenang dalam pengangkatan Perangkat Desa bukanlah pada Kepala Desa itu sendiri dengan kata lain Kepala Desa hanya berwenang untuk mengajukan calon Perangkat Desa yang terbaik yang telah melakukan Penjaringan.Kepala Desa Longeo Utama telah merekomendasikan beberapa calon yang dianggap layak untuk berhak menjadi perangkat Desa. Terdapat Tujuh Rekomendasi Kepala Desa untuk ditindak lanjuti oleh camat. Ke-tujuh Rekomendasi tersebut tidak ada hambatannya dan diterimah oleh Camat untuk di terbitkan SK (Surat Keputusan) Oleh Kepala Desa. Sekretaris Desa Longeo menjelaskan dalam hal bila rekomendasi calon Perangkat Desa tidak diterimah oleh Camat maka kepala Desa wajib untuk melakukan penjaringan ulang untuk merekrut Perangkat desa

\section{d. Kepala Desa Menerbitkan Keputusan Tentang Pengangkatan Perangkat} Desa

Penerbitan Surat Keputusa terkait pengangkatan Perangkat Desa di Desa Longeo Utama merupakan wewenang dari kepala desa tersebut sesuai dengan peraturan menteri Nomor 85 Tahun 2015 tentang pengangkatan dan pemberhentian perangkat desa. Kepala Desa Longeo Utama telah menerbitkan Surat Keputusan 
Kepala Desa Longeo Utama Nomor; 140/04/DLU Tahun 2018 Tentang Pengangkatan Perangkat Desa terkait pengangkatan Perangkat Desa setelah mendapatkan persetujuan dari camat

Dari hasil wawancara dengan Kepala Desa dan Ketua Panitia seleksi setelah merekomendasikan terhadap camat terkait tentang hasil penjaringan Perangkat Desa maka selambat- lambatnya 3 hari setelah rekomendasi di terimah membuat Surat Keputusan Namun bilamana rekomendasi yang telah dilakukan di tolak oleh camat maka Kepala Desa wajib menahan Surat Keputusan sampai pada dilakukan kembali penjaringan Calon Perangkat Desa. Surat keputusan tersebut merupakan hal yang mutlak yang harus di terimah oleh seluruh kalangan masyarakat Desa Lngeo Utama sebagai keputusan Kepala Desa yang telah melakukan penjaringan.

Berdasarkan uraian tersebut bahwa Kepala Desa Longeo Utama telah Melaksanakan wewenangnya dalam menerbitkan Surat Keputusan pengangkatan Perangkat Desa yang telah di setujuai oleh camat telah sesuai dengan peraturan menteri Nomor 85 Tahun 2015 tentang pengangkatan dan pemberhentian perangkat desa.

\section{Faktor yang mempengaruhi Rekrutmen Perangkat Desa}

\section{a. Faktor Pendukung Rekrutmen Perangkat Desa}

Adapun yang menjadi faktor pendukung dalam pelaksanaan rekrutmen perangkat desa adalah yang pertama ketersediaan papan informasi Desa, Dari hasil wawandara dengan kepala desa bahwa papan informasi menunjang kegiatan penyelenggaraan rekrutmen perangkat desa Desa Longeo Utama. Karena tidak mengambil waktu banyak dalam memberitahukan kepada masyarakat yang ingin ikut andil dalam proses rekrutmen perangkat desa di Desa Longeo Utama. Papan Informasi Desa memiliki berbagai fungsi bagi publik atau khalayak, Papan Informasi Desa memiliki peran untuk menghimpun berbagai informasi penting dan bernilai berita.

Kedua, adalah tempat pelaksanaan proses rekrutmen yang disediakan oleh Kepala Desa dan panitia pelaksana cukup nyaman dan luas yaitu bertempat di balai Desa Longeo Utama, sehingga orang-orang yang berada di tempat itu tidak merasa 
gelisah dengan keadaan temapat yang disediakan. Ketiga adalah kegiatan Sosialisasi langsung yang merupakan salah satu bentuk dukungan dari Kepala Desa untuk menyelenggarakan rekrutmen perangkat desa di Desa Longeo Utama karena mengingat masih banyak masyarakat Desa Longeo Utama yang Gaptek atau gagal teknologi dan ada juga yang masih belum mengerti tentang rekrutmen perangkat desa. Kepala Desa memberikan wewenang kepada panitia yang menyelenggarakan proses rekrutmen perangkat desa di Desa Longeo Utama. Fungsi dari Sosialisasi langsung yaitu member tahukan kepada masyarakat Desa Longeo Utama yang belum mengetahui rekrutmen perangkat desa tersebut dan menjelaskan kepada masyarakat secara langsung. Dari hasil wawanca dengan Ketua Panitia Seleksi bawah Kelengkapan berkas yang diberikan panitia oleh calon peserta rekrutmen perangkat desa, membuat kinerja panitia dalam melaksanakan rekrutmen perangkat desa di Desa Longeo Utama tidak terhambat oleh penundaan jadwal rekrutmen perangkat desa di Desa Longeo Utama.

\section{b. Faktor Penghambat Rekrutmen perangkat}

Ketersediaan anggaran merupakan salah satu faktor yang menghambat proses rekrutmen perangkat desa. Anggaran yang dikeluarkan pemerintah untuk proses pelaksanaan Seleksi tidak mencukupi dalam proses rekrutmen perangkat desa. Dari hasil wawancara dengan Kawela selaku Ketua Panitia Seleksi bahwa anggaran yang disediakan pemerintah Desa Longeo Utama tidak mencukupi dalam proses rekrutmen perangkat desa, karena ada banyak keperluan yang ingin disiapkan. Proposal yang diusulkan sekitar 12 juta namun yang disediakan hanya 5 juta

Faktor yang lain ialah rendahnya minat pendaftar dan sumber daya manusia penyelenggara. Berdasarkan hasil wawancara dengan Ketua Panitia Seleksi bahwa jumlah Peserta dalam proses rekrutmen perangkat desa di Desa Longeo Utama sangat minim, sehingga panitia rekrutmen perangkat desa berupaya dengan berbagai cara seperti bertemu langsung dengan masyarakat. Pada aspek Sumber daya manusia dari hasil wawancara dengan Kepala Desa Longeo Utama sulitnya mendapatkan sumber daya manusia yang baik yang memiliki kompetensi yang baik sehingga dalam pelaksanaan kegiatan Rekrutmen Perangkat Desa masih 
banyak kelemahan- kelemahan yang di dapatkan, dalam rekrutmen perangkat desa, perangkat desa harus belajar keras untuk bisa memahami dan mengikuti aturan yang sebenarnya karena pada awalnya perangkat desa tidak memahami alur proses rekrutmen.

\section{Kesimpulan}

Wewenang Kepala Desa Longeo Utama dalam melaksanakan Rekrutmen Perangkat Desa telah sesuai dengan peraturan menteri Nomor 85 Tahun 2015 adalah Kepala Desa dapat membentuk Tim yang terdiri dari seorang ketua, seorang sekretaris dan minimal seorang anggota, Kepala Desa melakukan penjaringan dan penyaringan calon Perangkat Desa yang dilakukan oleh Tim, Kepala Desa merekomemndasikan Calon Perangkat Desa yang telah melakukan penjaringan dan penyaringan kepada Camat untuk di berikan persetujuan atau penolakan berdasarkan persyaratan yang ditentukan, dan Kepala Desa menerbitkan Keputusan Kepala Desa tentang Pengangkatan Perangkat Desa. Dalam malaksanakan penjaringan Kepala Desa beserta Tim Seleksi Rekrutmen telah melakukan Sosialisasi, pemberkasan, tes tertulis, dan wawancara. Namun dalam penerapannya tahap wawancara belum bisa dilaksanakan sesuai dengan aturan yang berlaku dikarenakan Sumber Daya Manusia yang terbatas.

Dalam proses rekrutmen perangkat desa memiliki faktor penghambat dan pendukung jalannya rekrutmen Perangkat desa. Faktor penghambat yakni kurangnya anggaran untuk memaksimalkan kegiatan, dan rendahnya jumlah pendaftar yang berimplikasi pada sulitnya mendapatkan SDM yang mumpuni di bidangnya. Sedangkan faktor pendukung dalam rekrutmen perangkat desa yakni sudah adanya papan informasi yang terpercaya sebagai sumber informasi masyarakat, adanya kegiatan sosialisasi keliling yang dilakukan oleh tokoh masyarakat, dan adanya dukungan dari masyarakat Desa Longeo Utama untuk berpartisipasi dalam kegiatan rekrutmen tersebut.

\section{Referensi}


Miles, Matthew B. and A. Michael Huberman. (2005). Qualitative Data Analysis(terjemahan).Jakarta : UI Press.

Peraturan Menteri Dalam Negeri Republik Indonesia Nomor 85 Tahun 2015 Tentang Pengangkatan Dan Pemberhentian Perangkat Desa

Selvia, E. M., \& Rodiyah, I. (2020). Implementation of Village Staff Recruitment and Selection in Sidoarjo Regency. JKMP (Jurnal Kebijakan dan Manajemen Publik), 8(1), 23-28.

Undang-Undang Republik Indonesia Nomor 6 Tahun 2014 Tentang Desa

Widjaja, (2003), Otonomi Desa Merupakan Otonomi Yang Asli, Bulat dan Utuh, Jakarta: PT Raja Grafindo Persada.

\section{Wawancara}

Resmin, (2020) Kepala Desa Longeo Utama, Asera, 20 Januari 2020

Kawela, (2020), Ketua Panitia Proses Rekrutmen, Asera, 20 Januari 2020

Ramlia, (2020), Desa Longeo Utama, 20 Januari 2020

Asbudin, (2020). Sekretaris Desa Longeo Utama, Asera, 21 Januari 2020 